\title{
A "arte da malandragem" entre a farsa e a tragédia - uma narrativa dramática de longa duração
}

DOI: https://doi.org/10.22409/pragmatizes.v11i20.46951

\section{Gilmar Rocha ${ }^{1}$}

Resumo: A obra literária não é uma fala sobre a realidade, mas um modo de falar a sociedade. Com base nessa premissa etnográfica, o texto explora a relação simbólica da literatura com alguns momentos da história cultural e política brasileira desde o Império. O objetivo é analisar a mudança de significado da malandragem ao longo do tempo destacando suas aproximações e diferenças com outras categorias do imaginário cultural e político brasileiro como o favor, o jeitinho, a corrupção, que embora vistos com desconfiança e descrédito hoje, ainda assim revelam de forma densa e critica aspectos significativos da realidade contemporânea. Assim a "arte da malandragem", entendida como um conjunto de representações e práticas simbólicas, constitui uma narrativa de longa duração na qual se revela o drama de uma sociedade cuja história oscila entre a farsa e a tragédia.

Palavras-chave: Favor; malandragem; jeitinho; corrupção; farsa; tragédia.

El "arte de las artimañas" entre la farsa y la tragedia - una narrativa dramática de larga duración

Resumen: La obra literaria no es un discurso sobre la realidad, sino una forma de hablar a la sociedad. Basado en esta premisa etnográfica, el texto explora la relación simbólica de la literatura con algunos momentos de la historia cultural y política brasileña desde el Imperio. El objetivo es analizar el cambio de significado de malandragem a lo largo del tiempo destacando sus aproximaciones y diferencias con otras categorías del imaginario cultural y político brasileño, como el favor, el camino, la corrupción, que aunque se ve con recelo y descrédito hoy en día, todavía revela de una manera densa y crítica aspectos significativos de la realidad contemporánea. Así, el "arte de malandragem", entendido como un conjunto de representaciones y prácticas simbólicas, constituye una narrativa duradera en la que se revela el drama de una sociedad cuya historia oscila entre la farsa y la tragedia.

Palabras clave: Favor; engaño; sentido; corrupción; farsa; tragedia.

\footnotetext{
${ }^{1}$ Gilmar Rocha. Doutor Antropologia Cultural (PPGSA/IFCS/UFRJ). Professor do Departamento de Artes e Estudos Culturais (RAE) e do Programa de Pós Graduação Cultura e Territorialidades (PPCULT) da Universidade Federal Fluminense (UFF), Brasil. E-mail: gr@id.uff.br https://orcid.org/0000-0002-1398-3742
} 
The "art of trickery" between burlesque and tragedy - a long-lasting dramatic narrative

Abstract: This literary work is not a speech about reality, but a way of speaking to society. Based on this ethnographic premise, the text explores the symbolic relationship between literature and some moments of Brazilian cultural and political history since the Empire. The objective is to analyze the change in the meaning of trickery over time, highlighting its similarities and differences with other categories of Brazilian cultural and political imagery such as favor, the Brazilian way, the corruption, which although viewed with suspicion and discredit today, still reveal in a dense and critical way significant aspects of contemporary reality. Thus, the "art of trickery", understood as a set of symbolic representations and practices, constitutes a long-lasting narrative in which the drama of a society whose history oscillates between mock and tragedy is revealed.

Keywords: Favor; trickery; Brazilian way; corruption; humbug; tragedy.

\section{A "arte da malandragem" entre a farsa e a tragédia - uma narrativa dramática de longa duração}

\section{Introdução}

Este ensaio nasce de uma inquietação germinada com os acontecimentos dos últimos anos no país. O ponto de partida é a impressão de que vivemos hoje, à exemplo de outros momentos na história, uma infeliz repetição que traz de volta o apotegma de Marx n'O Dezoito Brumário de Luís Bonaparte quando ele diz: "Hegel observa em uma de suas obras que todos os fatos $e$ personagens de grande importância na história do mundo ocorrem, por assim dizer, duas vezes. E esqueceu-se de acrescentar: a primeira vez como tragédia, a segunda como farsa" (MARX, 1978, p. 329). Mas, nossa história parece ser mais trágica, talvez porque encompasse a farsa; invertendo, por assim dizer, o veredicto de Marx.

$O$ interesse pelo tema da malandragem no momento em que os escândalos de corrupção, então espetacularizados nos meios de comunicação tomam conta do país, denuncia mais do que uma farsa senão um trágico parentesco de origem que reverbera estruturalmente como gênero de drama social que atravessa nossa história desde ao menos o "tempo do rei" ${ }^{2}$, e que se acentua no curso da história republicana.

\footnotetext{
${ }^{2}$ Referência a frase inicial de Manuel Antônio de Almeida em Memórias de um sargento de milícias, romance que na leitura de Antônio Cândido (1988) introduz o malandro na novelística nacional brasileira.
} 
Qual o significado da malandragem no Brasil hoje? A pergunta tem razão de ser, pois o significado da malandragem no Brasil de ontem, parece nos conduzir a uma visão contrária ao drama vivido atualmente com relação aos escândalos de corrupção e de violência; muito embora escandalosa mesmo é a desigualdade social fenômeno estrutural - no "país da malandragem". Frente às inúmeras denúncias de corrupção que, para além dos escândalos trazidos à tona com a "Lava Jato"3, grassam nos mais variados setores da vida pública no país em nível municipal, estadual e federal, nas mais variadas áreas como saúde, educação, segurança, envolvendo empreiteiras, prestadores de serviços, políticos, milicianos, servidores públicos, empresários, juízes etc., a malandragem ganha contornos românticos e nostálgicos como símbolo de uma época distante

\footnotetext{
${ }^{3}$ Um dos mais famosos esquemas de corrupção já denunciado no país, cuja espetacularização política e moralista encapsula o verdadeiro problema da sociedade brasileira: a nossa colonial desigualdade social.
}

e, até certo ponto, de um "mundo sem culpa"4.

A verdade é que a malandragem constitui um sistema amplo, complexo e desafiador, se se leva em conta a multivocalidade das categorias que a compõem, tais como: favor, jeitinho, corrupção, gambiarra (NASCIMENTO, 2017). Embora subscrevam práticas sociais diferentes desenvolvidas ao longo do tempo, muitas vezes essas categorias são tomadas como sinônimas, por exemplo, Roberto DaMatta define o malandro um "profissional do jeitinho" (1986, p. 102). Podemos então nos perguntar: qual o grau de parentesco entre essas categorias? A corrupção de hoje é filha da malandragem de ontem? Há um continnum sociológico entre esses fenômenos? São eles a dupla face de Jano? Malandros, bandidos, políticos e milicianos, quiçá, empresários, são a expressão facial de um hipodigma? ${ }^{5}$ Sem pretender

\footnotetext{
${ }^{4}$ De certa forma, a tese do "mundo sem culpa", enunciada por Antônio Candido começa a ser idealizada já nos idos dos anos 1950, segundo Michel Misse (1999).

${ }^{5}$ Conceito utilizado por Cavalcanti Proença (1978), para caracterizar Macunaíma o herói sem nenhum caráter cujo significado remete a ideia do personagem ser portador de todos os caracteres conhecidos de determinada espécie, no caso, o malandro.
} 
estabelecer a hereditariedade entre uma e outra, interessa pensar o significado da malandragem ao longo do tempo tomando a literatura como caminho da análise simbólica.

A verdade é que o "país do carnaval, do futebol, do samba e da malandragem" é também o país das mazelas sociais, dos assassinatos de jovens negros pobres da periferia, da intolerância religiosa, do agronegócio e do agrotóxico, dos desmatamentos e das grilagens de terras indígenas, enfim, um país que parece fiel à sua história desde a colônia. À pergunta: Que país é este?; uma reposta, entre outras: este é o país entre os dez com pior índice de desigualdade social do mundo. "O país que não é sério e onde tudo acaba em festa", terra do "homem cordial" - comumente confundido com "doçura" ou "bondade natural" - ao mesmo tempo se revela desigual, violento, excludente e conservador. Farsa ou tragédia, eis a questão?

\section{Um drama social de longa duração}

Sem perder de vista a diversidade de tipos, práticas $\mathrm{e}$ representações que a "cultura da malandragem" incorporou na sociedade brasileira $^{6}$, tomo como ponto de partida a leitura de Lívia Barbosa (1992) sobre o "jeitinho brasileiro" a fim de expor meu argumento exploratório e, por isso mesmo, (in)conclusivo. Do ponto de vista da antropóloga, o "jeitinho" pode ser assim representado

estruturalmente:

$$
(+) /(-)
$$

Favor Jeito Corrupção

O esquema ilustra a dificuldade em se definir o "jeitinho" no universo social brasileiro, pois "o que é e o que não é jeito varia bastante", adverte-nos Barbosa (1992, p. 33): "Não existe um elemento que pudéssemos assinalar cuja presença configuraria uma situação que fosse definida por todos como jeito". Assim sendo, o jeitinho se localiza em meio às categorias afins "favor" e "corrupção" estabelecendo um continuum entre elas à medida que se aproxima ora positivamente de uma, ora negativamente de outra, convivendo muitas vezes

\footnotetext{
${ }^{6}$ Pode-se destacar desde a figura jurídica do vadio às figuras simbólicas do sambista, do valente, do cafajeste, do pilantra, do contraventor, do bicheiro, do "despachante", do "171" ao "bicho solto" e tantos outros.
} 
ROCHA, Gilmar. A "arte da malandragem" entre a farsa e a tragédia uma narrativa dramática de longa duração. PragMATIZES - Revista Latino-Americana de Estudos em Cultura, Niterói/RJ, Ano 11, n. 20, p. 358-385, março 2021.

transversalmente. À primeira vista, trata-se de um movimento interativo/conflitivo que varia no espaço e no tempo, muito embora o "favor" apresente maior sintonia com os sistemas de características tradicionais e a "corrupção" se aproxime dos sistemas sociais contemporâneos individualizados. A depender da situação, isso não impede de se ver a combinação desses expedientes em um mesmo personagem ou mesmo ambiente social simultaneamente.

Num exercício de "imaginação poética" (em devaneio com Bachelard, 1988) vejo nas obras de Manuel Antônio de Almeida (1988), Millôr Fernandes (1981), Chico Buarque de Holanda (1980) e Fernando Jorge (2003), a exemplo dos ritos de passagem, uma narrativa dramática sobre a mudança de status do malandro e da malandragem ao longo do tempo, protagonizada pelos personagens Leonardo Pataca, Max Overseas e Piranha da Fonseca Albuquerque (e seus contrários: Vidigal, Inspetor Chaves e os "militares"), cujo "parentesco simbólico" os vinculam à tradição malandra na cultura popular brasileira

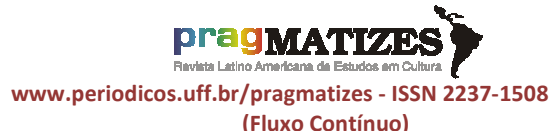

(Fluxo Contínuo)

na forma de literatura, teatro, música, cinema etc. $O$ conjunto dessas obras forma uma narrativa de longa duração na qual se revelam alguns dos dramas sociais mais arraigados no imaginário cultural brasileiro aqui, definido, como "arte da malandragem"7.

Não é demais lembrar que a literatura constitui uma espécie de narrativa etnográfica em que as obras literárias podem ser vistas como "narrativas míticas", sugere DaMatta (1993). Assim, combinando a dramatização ritual e a narrativa mítica que o conjunto das obras encenam, proponho uma análise em três tempos na qual se destaca: 1) a instituição do favor em meio as Memórias de um sargento de milícias; 2) embora as memórias do Vidigal, de Millôr Fernandes, também seja ambientada no "tempo do rei" constitui uma metáfora do Estado militarizado dos anos 1960, e divide com a Ópera do malandro, ambientada na Lapa dos anos 1940, o processo de

\footnotetext{
${ }^{7} \mathrm{~A}$ definição visa circunscrever o campo da observação e não a substância dos fatos (Mauss, 1981). O drama social, nos termos de Turner (2008), é entendido como metáfora ou modelo por meio do qual se pode apreender processualmente parte do comportamento social humano como ação simbólica. Sobre a relação imaginação e cultura ver Rocha (2016).
} 
"profissionalização" do malandro em tempos de modernização e populismo e de universalização do "jeitinho"; 3) a saga de "Piranha da Fonseca Albuquerque", protagonista de $\mathrm{O}$ grande líder, personagem corrupto inclinado à todo tipo de vilania que "para o bem de todos e a felicidade geral da nação" se sacrifica, ao candidatar-se à presidência da república visando salvar a pátria amada ${ }^{8}$.

Ao final, todo esse percurso nos leva a pensar, inconclusivamente: qual a eficácia simbólica da "arte da malandragem"para se pensar o Brasil hoje?

\section{A favor da malandragem}

"Era no tempo do rei". É assim que Manuel Antônio de Almeida inicia Memórias de um sargento de milícias, romance que na caracterização de Antônio Cândido (1988) imita a estrutura da sociedade brasileira do século XIX e revela a dialética da ordem e da desordem que a coloca em movimento. Leonardo filho, nascido de

\footnotetext{
${ }^{8}$ Sabe-se que momentos de crise nas sociedades são férteis para a emergência de líderes carismáticos, salvadores da pátria, anunciando um novo mundo (LINDHOLM, 1993).
}

uma "pisadela e um beliscão" tão logo aprendeu a "andar e falar tornou-se um flagelo": "Era, além de traquinas, guloso; quando não traquinava, comia. A Maria [a mãe] não the perdoava; trazia-Ihe bem maltratada uma região do corpo; porém ele não se emendava, que era também teimoso, e as travessuras recomeçavam mal acabava a dor das palmadas" (ALMEIDA, 1988, p. 11). Após ser abandonado pelo pai, Leonardo será criado pelo padrinho e dele receberá toda atenção e perdão pelos malfeitos na escola ou na sacristia. Em verdade, o padrinho haveria de protegê-lo até mesmo depois de morto, deixando-lhe algo em testamento.

Como bem observa Antônio Cândido (1988), suprimindo do romance as classes dominantes e o escravo, Manuel Antônio de Almeida coloca em destaque os setores baixo e médio da sociedade revelando a estrutura e a dialética que movimenta tanto as personagens do romance quanto a própria sociedade. $\mathrm{O}$ romance imita a história. Assim, é em meio ao jogo bruxuleante entre a ordem e a desordem que o malandro navega à exemplo da própria sociedade que ele representa. Embora 
longa, a citação a seguir ilustra o que o sociólogo desvela nas aventuras e desventuras de Leonardo Pataca no

Rio de Janeiro do "tempo do rei":

É burla e é sério, porque a sociedade que formiga nas Memórias é sugestiva, não tanto por causa das descrições de festejos ou indicações de usos e lugares; mas porque manifesta num plano mais fundo e eficiente o referido jogo dialético da ordem e da desordem, funcionando como correlativo ao que se manifestava na sociedade daquele tempo. Ordem dificilmente imposta e mantida, cercada de todos os lados por uma desordem vivaz, que antepunha vinte mancebias a cada casamento e mil uniões fortuitas a cada mancebia. Sociedade na qual uns poucos livres trabalhavam e os outros flauteavam ao deus-dará, colhendo as sobras do parasitismo, dos expedientes, das munificências, da sorte ou do roubo miúdo. Suprimindo o escravo, Manuel Antônio suprimiu quase totalmente o trabalho, suprimindo as classes dirigentes, suprimiu os controles do mando. Ficou o ar de jogo dessa organização bruxuleante fissurada pela anomia, que se traduz na dança dos personagens entre lícito e ilícito, sem que possamos afinal dizer o que é um e o que é o outro, porque todos acabam circulando de um para outro com uma naturalidade que lembra o modo de formação das famílias, dos prestígios, das fortunas, das reputações, no Brasil urbano da primeira metade do século XIX. Romance profundamente social, pois, não por ser documentário, mas por ser construído segundo o ritmo geral da sociedade, vista através de um dos seus setores. E sobretudo porque dissolve 0 que há de sociologicamente essencial nos meandros da construção literária" (CÂNDIDO, 1988, p. 209).

Não é preciso muito esforço para se perceber que toda essa "cultura da malandragem" que se desenvolve desde então, apresenta grande afinidade com a instituição do "favor" como nos sugere Roberto Schwarz em suas "Ideias fora do lugar". A categoria favor remete a um mundo de representações e práticas que no dizer de Schwarz (1981, p. 16) "atravessou e afetou no conjunto a existência nacional" desde a nossa formação colonial. O favor se constitui no mecanismo básico de estruturação das relações sociais, sobretudo, entre o senhor e os homens livres, já que o escravo permaneceu à margem por quase toda a colonização fora dessa "economia simbólica". "O favor é a nossa mediação quase universal", destaca o crítico literário, pois "sendo mais simpático do que $o$ nexo escravista, a outra relação que a colônia nos legara, é compreensível que os escritores tenham baseado nele a sua interpretação do Brasil, involuntariamente disfarçando a violência, que sempre reinou na esfera da produção", dirá o autor (SCHWARZ, 1981, p. 16). E, a se julgar o desfecho das Memórias de um sargento de milícias, de fato, na dialética da malandragem que estrutura e movimenta o romance e a 
ROCHA, Gilmar. A "arte da malandragem" entre a farsa e a tragédia uma narrativa dramática de longa duração. PragMATIZES - Revista Latino-Americana de Estudos em Cultura, Niterói/RJ, Ano 11, n. 20, p. 358-385, março 2021.

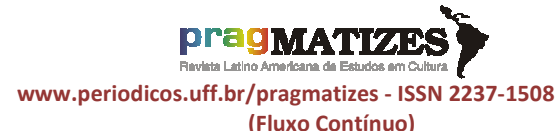

(Fluxo Contínuo) sociedade da época, o favor e o jeitinho são vividos dramaticamente pelas personagens Leonardo e seu algoz, Major Vidigal. Cada um à sua maneira irá contrariar o contrário. Em outras palavras, ao final do romance a personagem Leonardo filho perseguido duramente pelo Major Vidigal -, acaba se transformando em sargento da milícia e se casa com Luisinha - sua paixão desde a infância. Na verdade, sua promoção é o resultado de um sistema de trocas de favores, que envolve Leonardo e sua madrinha Dona Maria que para livrar o afilhado da prisão recorre a Maria Regalada, objeto de desejo de Vidigal que, no último momento, cede à promessa de uma vida em conjunto, ao que tudo indica? ${ }^{9}$.

André Bueno (2008) retoma a dialética da malandragem à luz da análise de Roberto Schwarz em "Pressupostos, salvo engano, de Dialética da malandragem" para destacar, salvo engano, o efeito da "redução estrutural" produzida pela

\footnotetext{
${ }^{9}$ Vale lembrar, a relação entre a polícia e a malandragem sempre foi tensa e ambígua, como se pode ver desde "Pelo telefone", gravada por Donga em 1910, a violenta relação do famoso marginal Lucio Flavio Lírio com o Esquadrão da morte nos idos de 1970, e os milicianos hoje (CANO; DUARTE, 2012).
}

análise de Antônio Candido sobre o texto de Manuel Antônio de Almeida. Ao enfatizar a supressão do senhor e do escravo e tomar como referência os setores intermediários da sociedade, Antônio Candido suprimiu a possibilidade do conflito, a "luta de classes", promovendo uma interpretação em sintonia com outros intérpretes do Brasil desde os anos 1930. Ratificando então a análise de Schwarz, Bueno se pergunta: "por que interpretar o Brasília partir desse específico setor da totalidade, dos que não trabalham regularmente, nem mandam e nem acumulam, localizando aí uma longa tradição, a própria dialética da malandragem?" (BUENO, 2008, p. 60). O efeito então da supressão do mundo do trabalho e do mando, e a fixação nos homens livres, porém, presos à cultura do favor, fez com que a análise de Antônio Cândido transformasse o que era próprio de um setor de classe em traço do ser nacional ${ }^{10}$.

\footnotetext{
${ }^{10}$ Essa proposição se estende há outras interpretações, por exemplo, Schwarcz (1995). Os historiadores João Reis e Eduardo Silva (1989), lembram que a escravidão não era de todo incompatível com o liberalismo, posto que todo um amplo e complexo sistema relacional de negociações, trocas e favores se infiltraria nas instituições sociais, econômicas etc., ocupando os espaços deixados em aberto pelo capital e a desigualdade social.
} 
ROCHA, Gilmar. A "arte da malandragem" entre a farsa e a tragédia uma narrativa dramática de longa duração. PragMATIZES - Revista Latino-Americana de Estudos em Cultura, Niterói/RJ, Ano 11, n. 20, p. 358-385, março 2021.

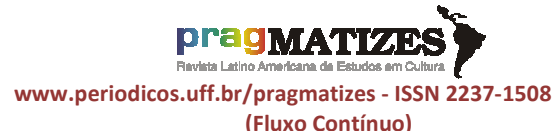

(Fluxo Contínuo)
Aos poucos a persona do malandro Leonardo filho -aqui entendido como símbolo de setores populares- irá dividir com outros malandros e não-malandros - ao menos não oficialmente trajando terno de linho branco e sapato de duas cores-, um modo mais universal e impessoal de malandragem que atravessa as práticas diárias de todo (sub)cidadão, até hoje. Não por acaso, na abertura da segunda parte do romance, Manuel vaticinava: "Já veem os leitores que a raça dos Leonardos não há de extinguir com facilidade" (CÂNDIDO, 1988, p. 93).

Um século após a publicação da obra de Manuel Antônio de Almeida, Millôr Fernandes trazia à público a sua versão das Memórias..., agora, do ponto de vista do Major Vidigal. Versão que apresenta maior sintonia com o tempo presente de sua encenação do que com o "tempo do rei". Um tempo que, de certa forma, guarda muitas afinidades com a Lapa dos anos 1940, da Ópera do malandro.

\section{A (des)ordem é a regra}

O cenário da Ópera do malandro é a Lapa dos anos 1940; o país vivia sob o Estado Novo. Obra inspirada na Ópera dos mendigos e Ópera dos três vinténs, de John Gay e Bertold Brecht \& Kurt Weill, respectivamente; a peça dramatiza o processo de modernização da malandragem. No filme homônimo, de Ruy Guerra (1986), a cena do "Desafio do malandro" é exemplar, pois ilustra o drama da disputa por certa imagem do malandro. O ambiente é o salão de bilhar, cronótopo da contenda entre malandros escolados cuja disputa ultrapassa a partida de sinuca para revelar-se um "jogo absorvente". O dueto é um duelo:

- Você tá pensando que é da alta sociedade

Ou vai montar exposição de souvenir de gringo

Ou foi fazer a fé no bingo em chá de caridade

Eu não sei não, eu não sei não

Só sei que você vem com five o'clock, very well, my friend

A curriola leva um choque, nego não entende

E deita e rola e sai comentando

Que grande malandro é você

- Você tá fazendo piada ou vai querer que eu chore

A sua estampa eu já conheço do museu do império

Ou mausoléu de cemitério, ou feira de folclore

Eu não sei não, eu não sei não

Só sei que você vem com reco-reco, berimbau, farofa

A curriola tem um treco, nego faz galhofa

E deita e rola e sai comentando

Que grande malandro é você

- Você que era um sujeito tipo jovial

Agora até mudou de nome

- Você infelizmente continua igual

Fala bonito e passa fome

- Vai ver que ainda vai virar 
ROCHA, Gilmar. A "arte da malandragem" entre a farsa e a tragédia uma narrativa dramática de longa duração. PragMATIZES - Revista Latino-Americana de Estudos em Cultura, Niterói/RJ, Ano 11, n. 20, p. 358-385, março 2021.

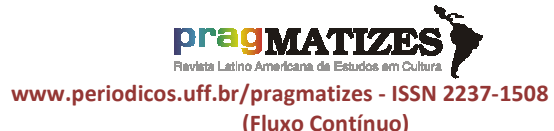

(Fluxo Contínuo) trabalhador

Que horror

- Trabalho a minha nega e morro de calor

- Falta malandro se casar e ser avô

- Você não sabe nem o que é o amor

Malandro infeliz

- Amor igual ao seu, malandro tem quarenta e não diz

- Respeite uma mulher que é boa e me sustenta

- Ela já foi aposentada

- Ela me alisa e me alimenta

- A bolsa dela tá furada

- E a sua mãe tá na rua

- Se você nunca teve mãe, eu não posso falar da sua

- Eu não vou sujar a navalha nem sair no tapa

- É mais sutil sumir da Lapa

- Eu não jogo a toalha

- Onde é que acaba essa batalha?

- Em fundo de caçapa

- Eu não sei não, eu não sei não

- Só sei que você perde a compostura quando eu pego o taco

A curriola não segura, nego coça o saco

E deita e rola e sai comentando que grande malandro é você (Ruy Guerra, Ópera do malandro, 1986).

Não fazia muito tempo, Noel Rosa e Wilson Batista também protagonizaram uma disputa em torno da imagem do malandro e que parece prolongar-se no jogo de bilhar entre Max Overseas e Sátiro Bilhar -cujo nome parece já antecipar o resultado da partida. Trajando seus indefectíveis ternos de linho branco S-120, Max é a versão moderna, progressista do malandro que se recusa "usar a navalha e a sair no tapa"; Sátiro lembra o lado tradicional, o malandro de antigamente, a encarnação folclórica de um personagem do "tempo do império". Tendo vencido a partida, Sátiro recusa a forma de pagamento proposta por Max -um isqueiro no valor de cem mil reis-, alegando não servir para percussão. Desmentindo a imagem consagrada no imaginário popular na qual o malandro usa a caixa de fósforo em substituição ao pandeiro, Max combina técnica corporal com criatividade e realiza uma pequena performance com $\mathrm{o}$ isqueiro de contrabando. À despeito das diferenças, em comum ambos se perguntam, afinal, que grande malandro é você?

$A$ verdade é que mais do que a modernização é o fantasma da tradição que parece assombrar o malandro dos tempos de Getúlio Vargas e da Segunda Guerra. O american way of life invade o Rio; o americanismo se abrasileira via a modernização conservadora e excludente. O cientista político Luís Werneck Vianna, em "O americanismo - da pirataria à modernização autoritária (e o que se pode seguir)", texto de apresentação à Ópera do malandro, lembra que no Brasil,

Ao contrário do padrão clássico de americanismo, a hegemonia burguesa não 'nascerá das fábricas'. Seu ponto de partida virá das 
ROCHA, Gilmar. A "arte da malandragem" entre a farsa e a tragédia uma narrativa dramática de longa duração. PragMATIZES - Revista Latino-Americana de Estudos em Cultura, Niterói/RJ, Ano 11, n. 20, p. 358-385, março 2021.

chamadas regiões supraestruturais, do Estado, da política, do Direito, que irão traçar 'de fora' pelas mãos dos nossos 'junkers' caboclos as linhas mestras do processo de modernização. E tempo há de rolar até que parte das novas frações burguesas se sinta em condições suprema audácia- de reivindicar para si o controle do arsenal político do Estado (VIANNA apud HOLANDA, 1980, p. 8).

E continua o autor, no Brasil "o novo se mantinha [e se mantém] preso ao passado. Nosso capitalismo continuava [e continua] preso com um pé na Lapa, em escusos galpões de fundo de praia, enlevado pelas mamatas, e nostálgico da capatazia de fazenda" (VIANNA apud HOLANDA, 1980 , p. 12). Impressiona a atualidade do texto de Vianna cuja ressonância nos lembra uma vez mais o apotegma de Marx com a diferença de que os fatos e os personagens de grande importância em nossa história ocorrem, por assim dizer, a primeira vez como farsa, a segunda como tragédia.

Em especial, a Ópera do malandro dramatiza esse processo de modernização dando destaque à visão de Terezinha -filha do cafetão Duran e de Vitória-, futura esposa do malandro Max Overseas. A moça tem tino empreendedor e incorpora a racionalidade empresarial no negócio

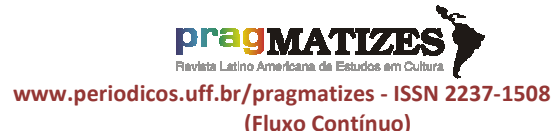

(Fluxo Contínuo)

de contrabando. Sua locução é eloquente:

Mas é claro, querido, é claro. Ninguém tá pedindo pra você mudar de atividade. Só o que precisa é dar um nome legal à tua organização. Põe um "esse-a" ou um "ele-tê-dê-a" atrás do nome e pronto, constituiu a firma. Firma de importações, por exemplo. É tão digno quanto contrabando e não oferece perigo. Você passa a ser pessoa jurídica, igualzinho ao papai. Pessoa jurídica não vai presa. Pessoa jurídica não apanha da polícia... Acho até que é imortal, pessoa jurídica (HOLANDA, 1980, p. 109).

\section{A malandragem deixa de ser} coisa de "malandrinhos" para se tornar ação racional, coisa de profissional. E, uma vez mais, é Teresinha quem vislumbra o futuro:

Sangue novo! A nova civilização! É claro que os malandrinhos, os bandidinhos e os que acham que sempre dá um jeitinho, esses vão apodrecer debaixo da ponte. Mas nesse povo aí fora não dá só vagabundo e marginal, não. $E$ vai ter um lugar ao sol pra quem quiser lutar e souber vencer na vida. É daí que vem o progresso, Max, do trabalho dessa gente e da nossa imaginação. Daqui a uns anos, você vai ver só. Em cada sinal de trânsito, em cada farol de carro, em cada nova sirene de fábrica vai ter um dedo da nossa firma. Você devia se orgulhar, Max (HOLANDA, 1980, p. 170).

A percepção progressista de Terezinha deve-se, talvez, ao fato de ser ela alguém que olha de fora e não estando envolta nas brumas da malandragem tradicional introduz sangue e espírito novo à tradição. 
ROCHA, Gilmar. A "arte da malandragem" entre a farsa e a tragédia uma narrativa dramática de longa duração. PragMATIZES - Revista Latino-Americana de Estudos em Cultura, Niterói/RJ, Ano 11, n. 20, p. 358-385, março 2021.

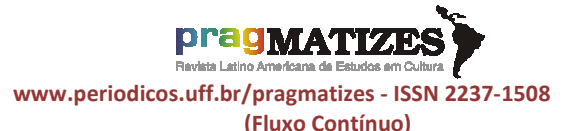

(Fluxo Contínuo)
Terezinha, sem exagero, é uma mediadora, penso em Velho e Kuschinir (2001). O resultado será a criação da Mastertex Ltda, empreendimento voltado para o ramo do "comércio exterior".

Como também adverte André Bueno a Ópera do malandro apresenta características empresariais modernas a se julgar "a metamorfose profunda na figura do malandro, que passava de simpático, boêmio, esperto mas boa gente, a arrivista sem escrúpulos, se aproveitando justamente da oscilação entre ordem e desordem trazida pela ditadura militar e da modernização autoritária do capitalismo" (BUENO, 2008 , p. 66). E pode-se dizer, acentuase também a metamorfose da polícia a se julgar a figura do Inspetor Chaves (o "Vidigal" de Max Overseas), como ilustra a passagem a seguir:

\begin{abstract}
É, eu sei que o momento é impróprio. Mas é que justamente hoje o meu outro sócio telefonou e me deu um aperto. Se tu não me paga, eu não posso pagar a ele. Também não posso chegar pra ele e dizer que tô duro porque o meu sócio contrabandista joga tudo no cassino e não paga o combinado. Não fica bem prum chefe de polícia, entende? Esse meu outro sócio é um homem muito sério. Cobra juros de vinte por cento ao mês (HOLANDA, 1980, p. $65)$.
\end{abstract}

Com o tempo, a aproximação do malandro com a polícia trouxe de volta a figura do miliciano, porém, travestido de nova significação como será visto à frente; personagem que irá, em alguns casos, também se aproximar e até fundir-se com a figura do político.

Michel Misse observa o "inicio da violência urbana" no Brasil a partir dos anos 1950, denunciando a passagem de uma ordem de crimes ainda marcados pelos roubos miúdos, pelos acertos de contas, pelos crimes de honra, a um cenário hoje marcado pelo narcotráfico, pelas ações de milicianos, pela política de "abate" do Estado, processo por ele definido como "acumulação social da violência", diz ele:

Se fizermos, e eu mesmo fiz essa pesquisa dos crimes comuns daquela época, nós vamos encontrar a predominância de crimes contra a propriedade, mas que não envolviam o uso da força física ou a sua ameaça. Encontramos também crimes contra a pessoa, mas, principalmente, lesões provocadas em brigas, em conflitos, algumas com ferimentos graves produzidos por armas de fogo, mas armas de fogo de baixo calibre, ou armas brancas, principalmente facas e navalhas. E havia, como já disse, muitos crimes passionais, muitos crimes ligados à honra, já que se tratava de uma sociedade tradicional que começava a se modernizar. Encontramos na literatura do período uma expressiva narrativa dessas questões, atualizada na literatura contemporânea pela irrupção da violência nos personagens. Entre as angústias passionais dos 
ROCHA, Gilmar. A "arte da malandragem" entre a farsa e a tragédia uma narrativa dramática de longa duração. PragMATIZES - Revista Latino-Americana de Estudos em Cultura, Niterói/RJ, Ano 11, n. 20, p. 358-385, março 2021.

personagens de Nelson Rodrigues, que podiam matar e se matar por ciúme e outras obsessões, e os personagens quase etnográficos de Paulo Lins, há uma vertiginosa ruptura, um abismo (MISSE, 2008, p. 375-376).

O sociólogo aponta ainda para o processo simultâneo

de reconhecimento do "jeitinho" como prática ligada à corrupção, pois "assim como essa violência ganhava legitimidade em razoáveis setores das polícias e da sociedade, também a corrupção deixava de ser representada como um desvio para ganhar a reputação de uma troca legítima, sob a égide do "jeitinho" brasileiro. Neutralizada a culpa, a troca passou a se desenvolver abertamente em diferentes contextos, sempre com a mesma justificação que levava empresários e profissionais liberais a sonegarem impostos: "não dar dinheiro a políticos e governos corruptos" (2008, p. 382). Não por acaso, Chico Buarque de Holanda irá capturar essa metamorfose da malandragem ao destacar em "Homenagem ao malandro" que;

Agora já não é normal O que dá de malandro Regular, profissional Malandro com aparato De malandro oficial Malandro candidato A malandro federal Malandro com retrato $\mathrm{Na}$ coluna social

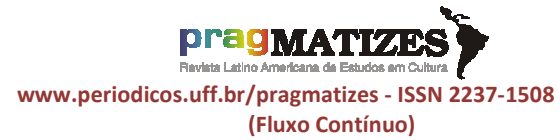

Malandro com contrato

Com gravata e capital

Que nunca se dá mal

(HOLANDA, 1980, p. 103).

Em paralelo à profissionalização do malandro e à universalização do jeitinho, o processo de modernização econômica da sociedade brasileira iniciada nos idos de 1940 e retomados nos anos 1970, exigiram uma estrutura de poder autoritária voltada para o controle das relações de produção e do trabalho internamente e favorável à penetração do capital internacional. Nesse sentido não é de se estranhar que a releitura de Millôr Fernandes das Memórias... acentue o ponto de vista da ordem. Ordem personificada por Vidigal, ordem capturada por Manuel Antônio de Almeida há mais de um século atrás, com ressonância ainda hoje ${ }^{11}$.

Não será diferente com Millôr Fernandes, pois prenunciando o tempo atual e antecipando $O$ grande líder, o multifacetado autor nos brinda com sua paródia Vidigal-memórias de um sargento de milícias, encenada em

\footnotetext{
${ }^{11}$ A máxima positivista "Ordem e progresso" parece ainda hoje mais viva do que nunca a dançar aos quatros ventos sob a égide e a narrativa dos moralistas, liberais e progressistas (numa curiosa combinação de religiosos, conservadores, setores liberais da classe média e mídia).
} 
1966, portanto, dois anos após o golpe militar de 1964. Logo na abertura, o "Padrinho", então o preceptor do malandro Leonardo, canta "A lei e a Ordem"; canção que parece feita para os dias de hoje:

Vivemos nos tempos do Rei

Tempo de Ordem e de Lei

Que Ordem, indagam, e que Lei?

(dá de ombros)

Ora, que Ordem?

Ora, que Lei?

Não sei.

Ah,

A Ordem é dos portugueses

-Os brasileiros também-

E a Lei é uma dureza

Pra quem não diz Amém. (Bis)

Com a força dominando

Um chefe policial

Dando, prendendo, tomando,

Uma figura bestial -bestial.

Todos que moram aqui

Neste Rio Imperial

Tremem de horror quando enfrentam

O Coronel (Bis) Vidigal (Bis).

(FERNANDES, 1981, p. 7-8).

Promovido a coronel, Vidigal é a incorporação do terror. E para ratificar - zeigesit ("espírito do tempo") conservador vivido naquele e nesses novos tempos, entra em cena o Exército da Salvação para cantar o "Auto-de-fé":

Nós somos todos

Homens de fé

A oração

É o nosso café

O pão do espirito

Nosso filé

Não consentimos
Álcool nem cama

Boca beijada

É mulher na lama

Tomem cuidado

Homens de fé

Cuja oração

É pão com café

E a comunhão

Um contrafilé

Comemos pouco

Nós não fumamos

Não temos filhos...

Nós nos poupamos

Nós nunca vimos

Homens de fé

Coisa na coisa

Como é que é

(...)

Tome cuidado,

Mocinha aflita

Cê goza a vida

Mas depois grita

Segura a saia

Com a tua fé

Não deixa entrar

Nenhum buscapé

(..)

Nenhum jacaré

Nenhum chimpanzé

E nenhum... José

(...)

Saia da frente

Vil pecador

Tua espada ofende

Nosso Senhor

(..)

Nós somos todos

Homens de fé

Nós só pecamos

Com a Santa Sé

(FERNANDES, 1981, p. 49-50).

Embora nascido no passado, Vidigal parece mesmo um agente do "tempo dos generais". Ainda hoje sua voz pode ser ouvida. Para o Vidigal 
ROCHA, Gilmar. A "arte da malandragem" entre a farsa e a tragédia uma narrativa dramática de longa duração. PragMATIZES - Revista Latino-Americana de Estudos em Cultura, Niterói/RJ, Ano 11, n. 20, p. 358-385, março 2021.

nada é proibido, só "É proibido não proibir" o que por ele for considerado permitido como mostra a peça:

Fica proibido o amor e o amar Fica proibido toda exibição (fecha o decote da moça)

Fica proibido olhar para o alto (rapaz que baixa a cabeça)

Fica proibido olhar pro chão (gesto indicando local. Soldado prega placa: "É proibido falar")

O cão ladra

Tem que ser punido (Entra cão com dono - deve ser um garoto vestido de cão- que Ihe coloca uma focinheira)

Rosto pintado não permito não (limpa boca de moça com lenço, mostra o lenço com nojo)

E conversinha de rapaz com moça (empurra uma velha horrenda pra junto de dois jovens que namoram)

Só com severa fiscalização

Fica proibido

Tudo que não for permitido (gesto.

Soldado prega placa: "É proibido calar")

E, por fim,

Fica proibido qualquer proibição

Não proibida por mim (sai com seus soldados)

(FERNANDES, 1981, p. 8-9).

Não demoraria, evidentemente, para que a resposta viesse com "Festa imodesta", uma homenagem ao compositor popular que pronuncia, malandramente, com arte e sabedoria "tudo aquilo que o otário silencia", canta Caetano Veloso. O jogo entre a ordem e a desordem não se restringe ao malandro, também o Poder é parte do jogo. Ambivalente, também a ordem se (des)faz em (des)ordem. É o que nos sugere André Bueno ao aprofundar o questionamento de

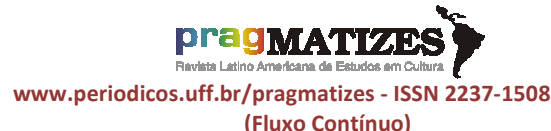

(Fluxo Contínuo)

Schwarz sobre o contexto da produção do ensaio de Antônio Candido que leva a pensar se "não seria a própria ditadura militar um modo de oscilação entre ordem e desordem"?:

\begin{abstract}
A ditadura militar rompeu as normas legais do país, desrespeitou o processo democrático, instalando em seguida um regime cujo vértice bárbaro foi a tortura. Abrindo caminho, graças aos grupos paramilitares do regime de exceção, ao que viria em seguida no Brasil, vale dizer, os Esquadrões da morte, parte fora da lei das polícias, e as diversas facções do crime organizado, misturadas que estavam, e continuam estando, com graus diversos de corrupção nas esferas da polícia, do judiciário, da política e, não menos importante, dos empresários que lucram com o tráfico de drogas e de armas, mas também de mercadorias roubadas. Sem esquecer que, no mesmo período, 0 assalto aos cofres públicos, a apropriação privada de verbas públicas, tornou-se quase que uma constante, num sistema político que, embora formalmente democrático, se acomoda a essas infrações da norma, equilibrando de modo perverso um sistema de interesses, de favores e de associações ilícitas, quase que a céu aberto (CÂNDIDO, 2008, p. 62).
\end{abstract}

Fazendo um jogo de palavras, com a ditadura militar se instaura a (des)ordem (des)legitimada.

resultado de todo esse processo é a metamorfose do malandro. A mudança de significado do malandro e da malandragem acaba por produzir uma visão até certo ponto nostálgica do 
ROCHA, Gilmar. A "arte da malandragem" entre a farsa e a tragédia uma narrativa dramática de longa duração. PragMATIZES - Revista Latino-Americana de Estudos em Cultura, Niterói/RJ, Ano 11, n. 20, p. 358-385, março 2021.

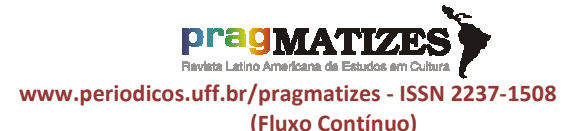

(Fluxo Contínuo) malandro, de antigamente, como observa Bueno (2008, p. 68):

Metamorfose a meu ver fundamental, que tirou de cena a figura do malandro como aquele que apenas quer escapar da disciplina do trabalho, um boêmio boa praça que não aceita a exploração e se vira nas beiradas do sistema. Daí não segue que o humor e a malícia tenham desaparecido do cotidiano e da cultura em nosso país. Mas, trazido à tona o ângulo negativo da malandragem, o humor e a malícia agora precisam ser pensados de modo crítico, cabendo sempre olhar com atenção, para distinguir as formas perversas da sociedade brasileira incorporadas à malícia e ao humor, portanto como riso que reconcilia, riso a favor do existente, riso que concorda com os dominadores e expõe ao ridículo os dominados, para lembrar aqui, de modo livre, uma posição de Theodor Adorno.

Acentuando essa linha de interpretação, João Cézar Rocha (2006) realiza análise crítica da "cultura da malandragem" tal qual canonizada desde a interpretação de Antônio Cândido, colocando em destaque um conjunto de representações contemporâneas sobre a violência e a desigualdade social que cada vez mais ganham visibilidade na sociedade brasileira. Assistimos na atualidade a superação parcial da dialética da malandragem pela dialética da marginalidade, ou nos termos do autor: "Reitero, então, a minha hipótese: a "dialética da malandragem" está sendo parcialmente substituída ou, para dizer o mínimo, diretamente desafiada pela "dialética da marginalidade", a qual está principalmente fundada, no princípio da superação das desigualdades sociais, através do confronto direto em vez da conciliação, através da exposição da violência em vez de sua ocultação" (ROCHA, 2006, p. 36). O jeitinho não desapareceu, mas tem sido desafiado a todo momento. A exacerbação da violência, a denúncia da exploração econômica, a crítica à negligência da diferença, muitas vezes expressas na produção cultural de filmes e na literatura como A cidade de Deus ou Quarto de Despejo, ratificam o sentido da dialética da marginalidade. Nas palavras do autor, a melhor definição "prática do que tenho chamado de "dialética da marginalidade" (...) é assumir controle da própria imagem, expressar-se com a própria voz" (2006, p. 50); o que a coloca em sintonia com a perspectiva dos estudos pós e decoloniais. $\mathrm{E} O$ malandro então se descobre um marginal brasileiro, como atestou Zé Keti em 1964, com Nega Dina: 
ROCHA, Gilmar. A "arte da malandragem" entre a farsa e a tragédia uma narrativa dramática de longa duração. PragMATIZES - Revista Latino-Americana de Estudos em Cultura, Niterói/RJ, Ano 11, n. 20, p. 358-385, março 2021.

\section{(...)}

Eu dou duro no baralho pra poder viver

A minha vida não é mole não

Entro em cana a toda hora

Sem apelação

Eu já ando assustado e sem paradeiro

Sou um marginal

Brasileiro

(KETI; MONSUETO, 1982).

Embora a idealização da malandragem na música, na literatura, no teatro, nas artes em geral, contribuísse para a formação de um tipo ideal caracterizado pela negociação, mediação, diálogo, ou seja, formas conciliatórias de resolução de normas em conflito, a violência nunca esteve ausente da vida cotidiana do malandro e de setores subalternos da sociedade como se pode ver desde as lutas corporais aos assassinatos por causa de jogos, disputas territoriais, lenocínio etc., (ROCHA, 2004). Portanto, a contraposição violência versus jeitinho deve-se possivelmente à mudança de percepção em torno da malandragem.

A verdade é que o "jeitinho", suposto modo harmonioso e conciliatório de resolução de conflitos sociais, também constitui uma forma de violência simbólica. Como nos lembra João Rocha: "Celebrar a malandragem, portanto, é esquecer que todo Vadinho

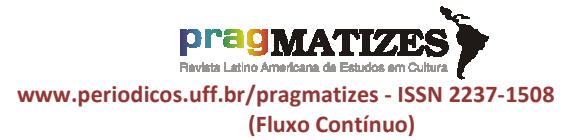

necessita de uma Dona Flor para explorar, roubar-lhe o dinheiro, agredila quando seu desejo não é prontamente atendido $\mathrm{e}$, como ninguém é de ferro, dar-lhe também amor" (ROCHA, 2006, p. 43). O malandro só sobrevive à custa do "otário". Mas, o otário, antes de ser um tipo, se parece com um ponto de vista, afinal, "o malandro pra valer -não espalha / aposentou a navalha..." (HOLANDA, 1980, p. 103), ou seja, o malandro pra valer tornou-se escada para o "malandro profissional". A verdade é que aos poucos, o malandro vai sendo dramaticamente encompassado por outras personas ou significantes, ora protagonizado pelo marginal narcotraficante que domina a comunidade, ora pelo miliciano violento e o político corrupto,muitas vezes, habitando um mesmo corpo.

\section{Moral da história}

Nesse momento, como que fechando o ciclo aberto com as Memórias..., o personagem Piranha da Fonseca Albuquerque d'O grande líder, texto de Fernando Jorge publicado em 1970, cobre um longo período histórico que se inicia em 1910 e vai até o golpe militar de 1964. A 
estória de Piranha é, na verdade, a saga da corrupção no Brasil, observa Ana Carolina Mesquita na orelha do livro $^{12}$.

Filho de um "coronel" violento e corrupto, Piranha, ao contrário de Leonardo Pataca, não é fruto de uma "pisadela e um beliscão", mas sim de um estupro. O nome que lembra a voracidade do peixe, Ihe foi dado em razão da fome insaciável; o que o torna "sósia" de Leonardo filho. Desde criança apresenta acentuada inclinação para o roubo; vício que o acompanha por toda vida. Em verdade, o pai lhe transmitira como "filosofia de vida" uma mensagem bem ao estilo do "parasitismo social", quando dizia: “- As saúva são ladrona - explicava Antônio a Piranha- mai eu num vô condená elas. A vida tudinha é um roubo! O fio rouba leiti da mãie, o têmpu nus rouba uscabêlu, u Guvêrnu rouba u povo cum impostu, u noivo rouba as fia do pai, a mórti nus rouba a respiração. Tudo é côpiangage!" (JORGE, 2003, p. 98). O estudo nunca foi o seu forte, mas chegou a ser

\footnotetext{
${ }^{12}$ Não faz muito tempo, o escritor e jornalista Fernando Jorge me surpreendeu com uma carinhosa e provocativa dedicatória ao me presentear com seu "O grande líder" - livro escatológico a se julgar a sua atualidade -, a ele minha modesta gratidão.
}

coroinha e a se formar em medicina; passava por meio de muita "cola", assédio e golpes. Como médico lançava mão de métodos bem simpáticos (relativo a práticas de magia simpática) para curar alguns de seus pacientes. Torna-se vereador e participa da Revolução de 1932, porém, mesmo com toda covardia que Ihe é atávica, acaba virando herói, o que favorece sua candidatura posterior a deputado federal. Embora discursasse em nome da liberdade e da democracia "no íntimo gostaria que um golpe abolisse o Senado e a Câmara Federal. Então, ó sonho maravilhoso!, ele assumiria o governo, convertendo-se em ditador absoluto, cuja primeira medida seria a imposição de um regime fascista, o aniquilamento da igualdade perante a lei, a supressão dos direitos e das liberdades constitucionais" (JORGE, 2003, p. 204), nos informa o escritor sobre seu personagem que parece ter vida própria. Não demoraria para que Piranha se lançasse ao Governo do Paraná pelo Partido Social Tropicalista, sendo eleito esmagadoramente. Em seus discursos proclamava:

Meu povo, meu querido povo, eu sou igualzinho a vocês, porque desde 
ROCHA, Gilmar. A "arte da malandragem" entre a farsa e a tragédia uma narrativa dramática de longa duração. PragMATIZES - Revista Latino-Americana de Estudos em Cultura, Niterói/RJ, Ano 11, n. 20, p. 358-385, março 2021.

cedo peguei no batente! Só aos quatorze anos calcei o meu primeiro par de sapatos! Sou filho de uma humilde datilógrafa, que logo ficou viúva e trabalhou em excesso para que eu pudesse estudar! É por isto que a mim não interessa a atividade político-partidária e embora eu seja liberal-democrata, sou um irredutível adversário dos privilégios da burguesia! Todavia, sempre defenderei as sagradas tradições da família paranaense e lutarei de peito descoberto contra os sistemas exóticos e anticristãos, pois o Evangelho de Nosso Senhor Jesus Cristo é o meu único código de moral!" (JORGE, 2003, p. 219).

Déjà-vu. Um discurso que lembra muitos políticos profissionais de hoje em dia: mentiras, populismo, conservadorismo etc.; nada que cause surpresa. Em sua gestão, na definição dos adversários políticos, a sede do Governo de Estado, o Palácio do Iguaçu, era conhecido como "Caverna do Ali Babá".

Em uma noite de insônia, o Secretário de Governo toma de um livro de Rui Barbosa a seguinte passagem na esperança de que o deus Morfeu dele se apiedasse, e leu para o Governador:

A natureza o fez escorregadio como a enguia, para as fugidas. Fê-lo como o camaleão, cambiante e multicor, para as adaptações mais variadas. Fê-lo com duas disposições do morcego para a dentada e o assopro, o afago e a sangria. Fê-lo rasteiro e virulento como a víbora, para as covardias e os crimes. Dotou-lhe o olhar do rato, as lágrimas do crocodilo, o riso da

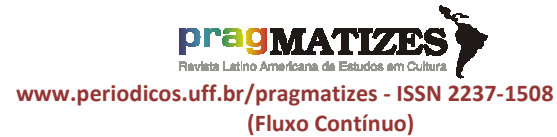

hiena, a gravidade do mocho, a imoralidade do bugio, a pele da anta, o bucho da ema" (JORGE, 2003, p. 241).

Para completar o perfil de Piranha, faltou a inteligência do asno; que seria atestada com o comentário a seguir: “- Puxa! O Rui Barbosa descreve um monstro! Será que existe alguém assim?" (JORGE, 2003, p. 241).

Ao fim e ao cabo, Piranha se lança a presidência do Brasil "e, tão logo a notícia, espalhou-se, causou maior regozijo entre os falsários, proxenetas, maconheiros, estupradores, arrombadores, peculatários, macumbeiros e contrabandistas" (JORGE, 2003, p. 284). Para finalizar, embora longa, vale a pena conhecer o seu desejo de Brasil novo e melhor, pois:

O seu programa de governo era bem simples: permitiria a entrada ilegal de estrangeiros no país; deixaria que vastas extensões do nosso território fossem leiloadas no Exterior, confinaria os adversários na ilha Fernando de Noronha; colocaria o Ministério da Fazenda a serviço de favoritismos inconfessáveis; ordenaria que nas escolas os alunos decorassem os versos da "Geração de 45", a fim de que a juventude se imbecilizasse; fundaria a Caixa da Poupança, no intuito de se apoderar dos níqueis do zé-povinho; aboliria o habeas-corpus, todo mundo poderia sofrer violência ou coação; chefiaria uma quadrilha de contrabandistas, os quais lhe trariam toneladas de ouro dos garimpos do Alto Tapajós; 


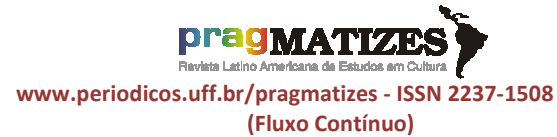

(Fluxo Contínuo)

instalaria em cada esquina um prostíbulo e em cada quarteirão uma casa de tavolagem; escolheria, como seus auxiliares, indivíduos analfabetos, inescrupulosos e subservientes; dilapidaria o patrimônio das autarquias, das empresas de economia mista e das concessionárias de serviços públicos; lindas meretrizes seriam rifadas pela Loteria Federal, a cinco mil cruzeiros o bilhete da dezena; sabendo que na China os mandarins se reciclavam no "divã do ópio", criaria para todos os brasileiros o "divã da maconha", porque desta forma os nossos patrícios ficariam cretinizados, com a inteligência embotada; limitaria ao mínimo a nossa produção agrícola, e de tal maneira que teríamos de importar cebolas do Egito, alhos do Chile, batatas da Holanda e rabanetes do Paraguai; incrementaria a indústria das matérias graxas do Estado, destinada à fabricação de sabonetes extraídas da gordura dos cadáveres; obrigaria os ginasianos a aprenderem História do Brasil nos livrescos inçados de erros do escrevinhador R. Magalhães Junior; organizaria o roubo e o crime, e neste sentido tomaria por modelo a célebre Murder Incorporated Company, que dominou Chicago na época de 1930; haveria de contratar eficientes assassinos da Máfia e da Camorra napolitana, assassinos tão frios e implacáveis como os mais terríveis gangsters dos Estados Unidos; entregaria à Bélgica, ou à Noruega, ou à Alemanha, as nossas jazidas de calcário e de areias monazíticas, as lavras de petróleo do Recôncavo baiano, os itabiritos da serra do Espinhaço, o manganês do Riacho de Santana, a bauxita de Paramirim, o cobre da mina Camacuâ, do Rio Grande do Sul, as riquezas do subsolo da região amazônica, os enormes depósitos de óxidos metaloides, as centenas de milhões de toneladas de ferro, de sulfatos de chumbo, de sal-gema, de volframita, de tantalita, de cassiterita e de dezenas de outras coisas terminadas em "ita"! (JORGE, 2003, p. 323-324).
Com fina ironia, ou para esconder a farsa dessa tragédia, Piranha concluía:

"- Eu sou o próprio retrato humano do Brasil! -bradou o candidato.

- Se esta nação tivesse que virar gente, viraria Piranha da Fonseca Albuquerque!" (JORGE, 2003, p. 325).

O que a saga de Piranha da

Fonseca Albuquerque nos revela, seguindo a linha aberta por Leonardo Filho, é a metamorfose do significado do malandro que, sem abandonar a dialética da ordem e da desordem, se torna símbolo de um fenômeno negativo. No entanto, não representa isso a superação da esperteza, da astúcia, da malícia $^{13}$, enfim, da malandragem como "poder dos fracos", para uma forma negativa de expressão cultural: a corrupção. "O malandro pra valer", diz o samba, permaneceu marginalizado, agora, não mais por Vidigal ou o Inspetor Chaves, mas pelos moralistas conservadores de ocasião. De certa forma, Piranha da Fonseca Albuquerque encarna, nele mesmo, um misto de político com miliciano; literariamente, é a

\footnotetext{
${ }^{13}$ A malicia, na leitura de Zonzon (2014), constitui um dos fundamentos do jogo da capoeira, inclusive, na constituição da capoeira como "arte da malandragem".
} 
ROCHA, Gilmar. A "arte da malandragem" entre a farsa e a tragédia uma narrativa dramática de longa duração. PragMATIZES - Revista Latino-Americana de Estudos em Cultura, Niterói/RJ, Ano 11, n. 20, p. 358-385, março 2021.

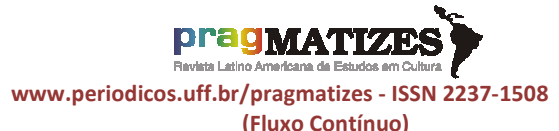

(Fluxo Contínuo) combinação tipo ideal da corrupção e da violência, da ignorância e da covardia.

A corrupção é, hoje, sem dúvida alguma o fantasma que ronda o Brasil. É o mal a ser combatido, o ente a ser expiado publicamente, o vilão a ser eliminado, o Estado a ser desestatizado; assim pensam certos juízes supremacistas, promotores lavajatistas, políticos olavistas, jornalistas globais, economistas neoliberais, pastores evangélicos, oportunistas de plantão, enfim, os "macarthistas" à la "tramp". O que mostra quão difícil e complexa é a tarefa de se tentar entender o nosso "Leviatã".

Em geral, os estudos sobre a corrupção no Brasil são unânimes em associá-la ao problema da formação do Estado. A interpretação clássica de Sérgio Buarque de Holanda em Raízes do Brasil, livro de 1936, de inspiração weberiana, caracteriza como patrimonial o Estado posto que para seus funcionários "a própria gestão política apresenta-se como assunto de seu interesse particular" (HOLANDA, 1984, p. 106) ${ }^{14}$. Consoante a esta

\footnotetext{
${ }^{14}$ A interpretação de Sergio Buarque de Holanda, como de outros intérpretes do Brasil,
}

perspectiva, outros veem na ausência de uma cultura cívica a causa da corrupção pois, nesse caso, imperam os interesses familiares, de grupos religiosos, empresarias etc. Há quem veja no descompasso entre a modernização e a estrutura burocrática tradicional o solo fértil para a corrupção, favorecendo muitas vezes a crença ou a ação egoísta com fins utilitaristas resultante de uma escolha racional. A verdade é que o número de abordagens sobre a corrupção não acompanha suas performances.

Seguindo a análise de Fernando Filgueiras (2009), inspirada na

será objeto de crítica virulenta da parte de Jessé Souza (2009; 2019); assunto que, em razão dos limites do texto, lamentavelmente não poderá ser aprofundado nesse momento. No entanto, destaco: A narrativa da "sociologia do jeitinho", da teoria do "homem cordial", entre outros, tem servido à legitimação do Estado patrimonial e da corrupção no Brasil não é falsa, mas não é absoluta. A vasta e longa legião de intérpretes que veem no favor, na malandragem, no jeitinho, na cordialidade, na corrupção, algo estruturante na realidade social precisa ser vista com profundidade e seriedade, pois não se reduzem a um discurso de legitimação ou retórica a favor da manipulação midiática arquitetada conspiratoriamente pelos intelectuais liberais conservadores com o conluio dos sistemas judiciário e legislativo e das elites do atraso. A realidade é sempre mais densa e complexa do que a teoria nos diz; não por acaso, Max Weber irá propor que se pense, com objetividade -por todo "aquele que ame a verdade"-, as configurações histórico-culturais da realidade social à luz dos "tipos ideais", colocando em destaque os elementos estruturantes da realidade sem, contudo, confundir-se empiricamente com a mesma. 
ROCHA, Gilmar. A "arte da malandragem" entre a farsa e a tragédia uma narrativa dramática de longa duração. PragMATIZES - Revista Latino-Americana de Estudos em Cultura, Niterói/RJ, Ano 11, n. 20, p. 358-385, março 2021.

sociologia de Bourdieu, nossa tolerância para com a corrupção decore da antinomia entre juízo de valor e juízo de necessidade. A corrupção se revela um jogo linguístico à medida que, a depender do juízo moral, as ações ou práticas consideradas corruptas são toleradas ou não; são condenadas ou não pela opinião pública. À exemplo do "tribunal da opinião" pública, de que fala Bourdieu (1988), no qual se avalia a honra de um homem, a corrupção é, antes de tudo, um juízo de valor, uma questão de moral. O que é corrupção para uns, pode não ser para outros. Julgada na esfera pública, porém, tolerada no âmbito da vida privada. Mas não é só na esfera da vida privada que o julgamento sobre a corrupção se relativiza, pois como nos mostra Otávio Bezerra (2017) os limites entre a ação de empreiteiras e dos políticos é bastante tênue. Nessa perspectiva, talvez não estejamos ainda, quem sabe, tão longe do "mundo sem culpa" do qual falava Antônio Candido décadas atrás.

Junto com a espetacularização da corrupção, sob a qual se produz um certo desvio de atenção sobre realidade da desigualdade social à

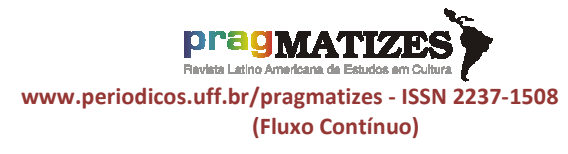

medida que se culpabiliza o Estado, a sua ressonância é reveladora de uma "tragédia disfar(s)çada" -a se julgar o sentido etimológico da palavra corrupção (do grego diaphthora) cujo significado remete à "destruição, ruína e dano aos valores e à ordem", nos lembra Gomes (2010, p. 33). A destruição da ordem social democrática e do estado mínimo de direitos, a sonegação de impostos das grandes empresas, a farra dos bilhões para 0 fundo eleitoral, o "empoderamento" das milícias, a orgia das fake news, tudo isso e muito mais, mostra que a corrupção -a ponta do iceberg- é antes a nossa farsa, por assim dizer, de uma história trágica. Desnecessário lembrar que a corrupção perpetrada pelos nossos "junkers", penso nesse momento em Werneck Vianna, alimenta a desigualdade social. Mas, é preciso um "bode expiatório" para se aplacar ou satisfazer a violência inerente à sociedade, sobretudo, quando a mesma apresenta características coloniais, quiçá escravocratas, como a brasileira $^{15}$.

\footnotetext{
${ }^{15}$ Do ponto de vista funcional a retórica da corrupção não escolhe partidos, classes ou religião, a se julgar o exemplo de Angola, pois, muitas vezes, o combate à corrupção se
} 
ROCHA, Gilmar. A "arte da malandragem" entre a farsa e a tragédia uma narrativa dramática de longa duração. PragMATIZES - Revista Latino-Americana de Estudos em Cultura, Niterói/RJ, Ano 11, n. 20, p. 358-385, março 2021.

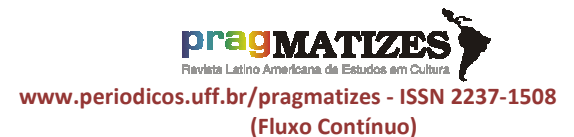

(Fluxo Contínuo)
Não por acaso, canta Chico Buarque de Holanda(1980, p. 21-23): "O malandro / Na dureza / Senta à mesa / Do café / Bebe um gole / De cachaça / Acha graça / E dá no pé", será, rocambolescamente, considerado o culpado, pois " $\mathrm{O}$ garçom vê / Um malandro / Sai gritando / Pega ladrão / E o malandro / Autuado / É julgado e condenado / Pela situação". E o que também denuncia Jessé de Souza (2009; 2019) quando diz que o malandro, o jeitinho e a corrupção funcionalmente legitimam essa chamada "pátria amada Brasil" ao tirar de cena o problema da desigualdade estrutural que persiste no país desde o "tempo do rei".

\section{A "arte da malandragem"}

Não há dúvida que as categorias favor, jeitinho, malandragem, corrupção, cordialidade, concorrem funcionalmente para a legitimação da retórica moralista, liberal e conservadora; no entanto, elas também apontam para um

aproxima de uma obsessão moral. Segundo Macamo (2014), em Angola a corrupção, independentemente de ser provada sua existência, representava uma ameaça à criação de um país novo, de um "homem novo" -fantasia que ronda o Brasil atualmente. conjunto de representações e práticas sociais daqueles que estão, muitas vezes, na outra ponta do sistema: aquela parcela gigantesca do mundo social brasileiro que a "elite do atraso" teima em tornar invisível e execrável: a "ralé brasileira". A verdade é que o mundo da malandragem não é um mundo cor de rosa onde tem lugar somente a negociação, as trocas, os favores, os golpes, os jeitinhos, enfim, as táticas harmoniosas de resolução de conflitos sociais. Antes, trata-se do mundo da vida cotidiana, o mundo da "realidade suprema" diria Schutz, marcado pela tensão e violência física e simbólica, na guerra de todos contra todos, ordinariamente. A malandragem talvez expresse simbolicamente a nossa forma de "lutas de classe", sem excluir a violência física ou simbólica, mas também sem abandonar a astúcia e a malícia que também hoje andam pervertidas. Até pouco tempo atrás, e possivelmente ainda hoje, a malandragem era parte de um estilo de vida e visão de mundo, portanto, uma forma de sociabilidade na qual as tensões, os conflitos, a violência, são intestinas ao sistema social (ROCHA, 2004). A música, a literatura, a indumentária, o cinema, o corpo, a 
ROCHA, Gilmar. A "arte da malandragem" entre a farsa e a tragédia uma narrativa dramática de longa duração. PragMATIZES - Revista Latino-Americana de Estudos em Cultura, Niterói/RJ, Ano 11, n. 20, p. 358-385, março 2021.

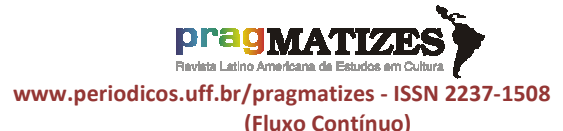

(Fluxo Contínuo) preguiça e tantas outras formas simbólicas por meio das quais se critica, se denuncia, se relativiza, se revela e se disfar(ç)sa a tragédia nossa de todo dia no "país do carnaval, do futebol e da malandragem", tudo isso nos mostra quão densa, profunda e complexa é a vida social no Brasil, mais do que o pensamento sociológico consegue às vezes tipificar. De certa forma, a malandragem expressa a sabedoria popular de enfrentar, com certo improviso, o sentido trágico da vida com "arte", no sentido nietzscheano.

É sabido que o significado das palavras, conceitos ou categorias não se mantem os mesmos de sempre, pois mudam com o tempo. Parafraseando com Gilberto Vasconcellos (1977, p. 101-102) “o vate português: muda-se o tempo, muda-se o vadio. Pisar macio já não é mais fundamental à malandragem". Não significa isso, no entanto, o fim ou a morte da malandragem. Em constante estado de prontidão 0 malandro e a malandragem se metamorfosearam ao longo do tempo e adquiriram outros nomes, outras caras, outras vozes. Assim, mesmo com toda ambiguidade e ambivalência de que é portadora, a "arte da malandragem", aquela utilizada pelos setores das classes populares, não representa, por certo, somente um modo de "domesticar as contradições", mas expressa uma forma simbólica de resistir, criticar, "empoderar" no sentido de desestabilizar e relativizar certas estruturas de poder, um modo de tornar o medo, a desigualdade, o preconceito, sem perder de vista a realidade suprema, em "letras de samba" enquanto "arma dos fracos"16.

Ao longo da formação das artes e das culturas populares no Brasil (literatura, teatro, poesia, música etc.) muitos tipos de malandros surgiram ora aqui, ora acolá como o malandro valente, o malandro regenerado, o bom malandro e o falso malandro, o malandro federal, o malandro sambista, entre outros. A poética musical de Bezerra da Silva ilustra esse processo ao dar voz, por meio

\footnotetext{
${ }^{16}$ Bakhtin (1987), confere às classes populares um grande poder de carnavalização, o que não está restrito ao universo da Idade Média e do Renascimento. Ao meu ver "etnografia experimental" de Telles e Hirata (2007) em torno das "histórias minúsculas" de "homens infames" -aqueles que vivem nas margens e à margem, entre o formal e o informal, o legal e o ilegal, o lícito e o ilícito-, ilustra de maneira exemplar e aproximativamente as tessituras da "arte do contornamento" com a "arte da malandragem".
} 
ROCHA, Gilmar. A "arte da malandragem" entre a farsa e a tragédia uma narrativa dramática de longa duração. PragMATIZES - Revista Latino-Americana de Estudos em Cultura, Niterói/RJ, Ano 11, n. 20, p. 358-385, março 2021.

das parcerias e dos tipos que canta, às parcelas menos favorecidas da sociedade como os habitantes das comunidades pobres, dos morros e dos subúrbios. Como nos lembra Leticia Vian (1998, p. 123-124):

Os sambas que Bezerra da Silva canta não fazem apologia do bandido, do malandro, do colarinhobranco corrupto ou do trabalhador. Falam, com humor ácido, de um mundo bárbaro, de certa forma pouco familiar ao grande público. Exploram uma linguagem própria marcada pela ambiguidade, pelo duplo sentido e ironia e pela relatividade ou ausência de julgamento moral; um discurso que afirma a identidade de um etos favelado, excluído dos mecanismos de justiça social. Seu repertório é uma crônica da vida cotidiana das favelas e subúrbios cariocas, crônica bem-humorada e densa de crítica social, onde o malandro é personagem ambíguo, difuso, que aparece de diferentes maneiras, inclusive como personificação do artista.

Em "Revisitando

a

malandragem", José Carlos Rodrigues (2018) retoma o modelo analítico de Roberto DaMatta centrado nas figuras do malandro, do Caxias, do otário e do renunciador, substituindo este último pelo bandido com fins a atualizar nosso imaginário; e observa: "não é mais possível hoje em dia, para entender o nosso cenário social, continuar fazendo confusão entre malandro e bandido. Também não se os pode ver como associados somente

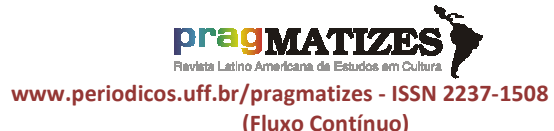

(Fluxo Contínuo)

às classes inferiores e ao gênero masculino", afinal, "Na prática social e no imaginário, o significado da palavra "malandro" vem se transformando, indicando uma concepção nova" (RODRIGUES, 2018, p. 8-9). A malandragem, para o antropólogo, "que está surgindo e se difundindo significa especialmente um tipo de intuição, uma espécie de sociologia nativa, sobre os modos de aplicação das regras no Brasil” (2018, p. 9). Para ilustrar essa nova significação, ele recorre à descrição de vários episódios capturados no cotidiano nos deixando ver que uma certa malandragem continua viva e até se universalizou. $\mathrm{O}$ malandro já não é mais substantivo, mas adjetivo referente a um tipo de comportamento social ou de ação simbólica.

Em suma, da milícia do sargento à milícia hoje, investida com novas patentes, há uma distância enorme entre uma e outra. A malandragem no sentido amplo do termo, é um gênero de razão astuciosa comum aos setores populares que lançam mão dessa prática todas as vezes que o poder visa silenciar sua voz, disciplinar seus gestos, apagar suas histórias. Sem apologia, a 
ROCHA, Gilmar. A "arte da malandragem" entre a farsa e a tragédia uma narrativa dramática de longa duração. PragMATIZES - Revista Latino-Americana de Estudos em Cultura, Niterói/RJ, Ano 11, n. 20, p. 358-385, março 2021.

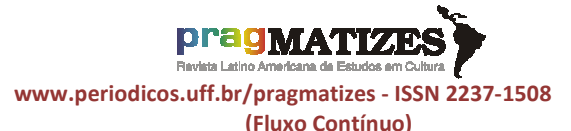

(Fluxo Contínuo) malandragem é antes de tudo, uma prática discursiva que pode ser utilizada positiva ou negativamente. $E$ pode ser tão crítica e fecunda quanto as leituras políticas ou sociológicas da realidade social, nos ensinam desde os interacionistas simbólicos aos etnometodólogos; pois não é demais lembrar o quanto o malandro e a malandragem têm sido perseguidos ao longo da história desde o tempo do rei passando pelo tempo de Getúlio (MATOS, 1982), chegando ao tempo da ditadura militar (VASCONCELLOS, 1977); tudo por conta de sua potência simbólica subversiva. No entanto, isso não elimina o fato de que vivemos a consciência infeliz em torno de um projeto político que (dis)far(s)ça a trágica perversidade de uma governança miliciana em curso hoje no país.

\section{Referências bibliográficas}

ALMEIDA, Manuel Antônio. Memórias de um sargento de milícias. São Paulo: Círculo do Livro, 1988.

BACHELARD, Gaston. A poética do devaneio. São Paulo: Martins Fontes, 1988.

BAKHTIN, Mikhail. A cultura popular na idade média e no renascimento: o contexto de François Rabelais. São Paulo: Hucitec ; Brasília: UnB, 1987.
BARBOSA, Lívia. O jeitinho brasileiro a arte de ser mais igual que os outros. Rio de Janeiro: Campos, 1992.

BEZERRA, Marcos Otavio. Corrupção e produção do Estado. REPOCS, São Luís, v. 14, n. 27, p. 99-130, 2017.

BOURDIEU, Pierre. O sentimento da honra na sociedade cabília. In: PERISTIANY, J. (org.). Honra e vergonha -valores das sociedades mediterrânicas. Lisboa: Fundação Calouste Gulbenkian, 1988. p. 157195.

BUENO, André. A dialética e a malandragem. Revista Letras, Curitiba, n. 74, p. 47-69, 2008.

CANDIDO, Antônio. Dialética da malandragem (caracterização das Memórias de um sargento de milícias). In: ALMEIDA, Manuel Antônio de. Memórias de um sargento de milícias. São Paulo: Círculo do Livro, 1988. p. 187-217.

CANO, Ignácio; DUARTE, Thaís (coords.). No sapatinho -a evolução das milícias no Rio de Janeiro (20082011). Rio de Janeiro: Fundação Heinrich Boll, 2012.

CAVALCANTI PROENÇA, Manuel. Roteiro de Macunaíma. Rio de Janeiro: Civilização Brasileira, 1978.

DAMATTA, Roberto. A obra literária como etnografia - notas sobre as relações entre literatura e antropologia. In: Conta de mentiroso - sete ensaios de antropologia brasileira. Rio de Janeiro: Rocco, 1993, p. 35-58.

DAMATTA, Roberto. O que faz o brasil, Brasil? Rio de Janeiro: Rocco, 1986.

FERNANDES, Millôr. Vidigal memórias de um sargento de milícias. Porto Alegre: L\&PM, 1981. 
ROCHA, Gilmar. A "arte da malandragem" entre a farsa e a tragédia uma narrativa dramática de longa duração. PragMATIZES - Revista Latino-Americana de Estudos em Cultura, Niterói/RJ, Ano 11, n. 20, p. 358-385, março 2021.

FILGUEIRAS, Fernando. A tolerância à corrupção no Brasil -uma antinomia entre normas morais e prática social. Opinião pública, Campinas, v. 15, n. 2, p. 386-421, 2009.

GOMES, José Vitor. A corrupção em perspectivas teóricas. Teoria \& Cultura, Juiz de Fora, v. 5, n. 1 e 2, p. 21-33, 2010.

HOLANDA, Chico Buarque de. Ópera do malandro. São Paulo: Cultura Editora, 1980.

HOLANDA, Sergio Buarque de. Raízes do Brasil. Rio de Janeiro: José Olympio, 1984.

JORGE, Fernando. O grande líder romance satírico, bárbaro, picaresco, baseado em fatos reais, nas cenas surrealistas da vida social e política de um país latino-americano chamado Brasil. São Paulo: Geração editorial, 2003.

LEITE, Dante Moreira. O caráter nacional brasileiro - história de uma ideologia. São Paulo: Pioneira, 1983.

LINDHOLM, Charles. Carisma -êxtase e perda de identidade na veneração ao líder. Rio de Janeiro: Jorge Zahar, 1993.

MACAMO, Elísio. Corrupção. In: SANSONE, Lívio; FURTADO, Claudio (orgs.). Dicionário crítico das ciências sociais dos países de fala oficial portuguesa. Salvador: EDUFBA, 2014. p. 59-73.

MARX, Karl. O 18 Brumário de Luís Bonaparte. In: GIANOTTI, José. (org.). Manuscritos econômico-filosóficos e outros textos escolhidos. São Paulo:Abril Cultural, 1978. p. 323-404.

MATOS, Claudia. Acertei no milhar samba e malandragem no tempo de Getúlio. Rio de Janeiro: Paz e Terra, 1982.

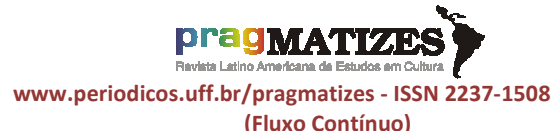

(Fluxo Contínuo)

MAUSS, Marcel. Ensaios de sociologia. São Paulo: Perspectiva, 1981.

MISSE, Michel. Malandros, marginais e vagabundos \& a acumulação social da violência no Rio de Janeiro. Tese (Doutoramento em Sociologia), Instituto Universitário de Pesquisas do Rio de Janeiro (IUPERJ), Rio de Janeiro, 1999.

MISSE, Michel. Sobre a acumulação social da violência no Rio de Janeiro. Civitas, Porto Alegre, v. 6, n. 3, p. 371385, 2008.

NASCIMENTO, Marcelle. A positivação do "jeitinho brasileiro" na mídia -uma reconfiguração do estereótipo identitário nacional. Dissertação (Mestrado em Cultura e Territorialidades), Universidade Federal Fluminense, Niterói, 2017.

REIS, João José; SILVA, Eduardo. Negociação e conflito -a resistência negra no Brasil escravista. São Paulo, Companhia das letras, 1989.

ROCHA, Gilmar. A imaginação e a cultura. Teoria \& Cultura, Juiz de Fora, v. 11, n. 2, p. 167-187, 2016.

ROCHA, Gilmar. O rei da LapaMadame Satã e a malandragem carioca. Rio de Janeiro: 7 Letras, 2004.

ROCHA, João Cezar, A guerra de relatos no Brasil contemporâneo -Ou: a dialética da marginalidade. Letras, Santa Maria, n. 32, p. 23-70, 2006.

RODRIGUES, José Carlos. Revisitando a malandragem. Alceu, Rio de Janeiro, v. 19, n. 37, p. 6-15, 2018.

SANTOS, Boaventura de Sousa. Para além do pensamento abissal - das linhas globais a uma ecologia dos saberes. In: SANTOS, Boaventura; 
MENESES, Maria Paula (orgs.). Epistemologias do Sul. Coimbra: Almedina, 2009, p. 23-71.

SCHWARZ, Roberto. As ideias fora do lugar. In: Ao vencedor as batatas forma literária e processo social nos inícios do romance brasileiro. São Paulo: Duas Cidades, 1981. p. 13-28.

SOUZA, Jessé. A elite do atraso -da escravidão a Bolsonaro (edição revista e ampliada). Rio de Janeiro: Estação Brasil, 2019.

SOUZA, Jessé. A ralé brasileira quem é e como vive. Belo Horizonte: UFMG, 2009.

TELLES, Vera; HIRATA, Daniel. Cidade e práticas urbanas -nas fronteiras incertas entre o ilegal, o informal e o ilícito. Estudos Avançados, São Paulo, v. 21, n. 61, p. 173-191, 2007.

TURNER, Victor. Dramas, campos e metáforas -ação simbólica na sociedade humana. Niterói: EDUFF, 2008.

VASCONCELLOS, Gilberto. Música popular -de olho na fresta. Rio de Janeiro: Graal, 1977.

VELHO; Gilberto; KUSCHINIR, Karina (orgs.). Mediação, cultura e política. Rio de Janeiro: Aeroplano, 2001.

VIANNA, Letícia. Bezerra da Silva: produto do morro- trajetória e obra de um sambista que não é santo. Rio de Janeiro: Jorge Zahar, 1998.

WEBER, Max. A 'objetividade' do conhecimento nas ciências sociais. In: COHN, Gabriel (org.). Weber: sociologia. São Paulo: Ática, 1986. p. 79-127.

ZÉ KETI; MONSUETO. História da música popular brasileira. São Paulo: Abril Cultural, 1982.
ZONZON, Christine. Capoeira algumas versões da malicia. Revista de Humanidades e Letras, Salvador, v. 1 , n. 1, p. 45-81. 